\title{
Characteristics of the clinical development of a newborn with gastroschisis in an intensive care unit in latin america
}

\author{
Ana Carolina Redondo ${ }^{1}$, Rubens Feferbaum ${ }^{2}$, Renata Amato Vieira ${ }^{2}$, \\ Daniel de Albuquerque Rangel Moreira ${ }^{1,3}$, Uenis Tannuri ${ }^{1,3}$, Werther Brunow de Carvalho ${ }^{1,2}$, \\ Maria Esther Jurfest Rivero Ceccon ${ }^{1,3}$
}

DOI: http://dx.doi.org/10.7322/jhgd.119266

\begin{abstract}
Introduction: Congenital malformations are major diseases observed at birth. They are the second most common cause of death in the neonatal population, the first one being prematurity.

Objective: To characterise the clinical outcome of newborns with gastroschisis (GS) in a neonatal intensive care unit.

Methods: A retrospective observational clinical study in 50 infants with GS using the association of intestinal abnormalities, impossibility of primary closure of the abdominal defect and reoperation necessity as classification criteria for the disease. The significance level was $p<0.05$.

Results: The hospitalisation to primary surgery occurred with a median age of 2 hours. Fourteen percent of children were subjected to a primary silo interposition and $24 \%$ had associated intestinal malformation. Nineteen newborns (NB) required more than one surgery. The median length of stay was 33 days, higher in patients with complex GS (56 days). All NB recovered from urine output 48 hours after surgery and $40 \%$ had hyponatraemia and oligoanuria in this period. There was no difference between the natraemia and fasting time $(p=0.79)$. Weight gain was similar in both groups with total parenteral nutrition and became significantly higher in patients with simple GS after enteral feeding $(p=0.0046)$. These NB evolved 2.4 times less cholestasis. Late-onset sepsis occurred in $58 \%$ of patients and was related to the infection of the central venous catheter in $37.9 \%$ of cases. Mortality was higher in infants infected with complex GS and the overall mortality rate was $14 \%$.
\end{abstract}

Conclusion: Clinical characterisation of newborns with gastroschisis depends on the complexity and the knowledge and conduct of morbidities to reduce mortality.

Key words: gastroschisis, new-born, mortality, total parenteral nutrition, renal insufficiency, infection.

\section{INTRODUCTION}

Congenital malformations are major diseases observed at birth. In the United States, a prevalence of about $3 \%^{1}$ is cited. In Brazil, a study at the Fernandez Figueira Institute in Rio de Janeiro found that the prevalence was similar, i.e. 2.7\% among live newborns (NB) and 6.7\% among stillbirths. Among the causes of death, neonatal malformations are the second most common reason, the first one being prematurity².

Gastroschisis (GS) is a congenital malformation of the abdominal wall that has increased in prevalence worldwide; its causes have not been fully elucidated ${ }^{3}$. In the 1960s, the prevalence of this disease was 1:50,000 live births. However, Kirby et al. ${ }^{4}$ recently reported that in the period from 1995 to 2005 in the United States, there was a

1 Médica Pediatra, Neonatologista e Mestre em Ciências pela Faculdade de Medicina da Universidade de São Paulo (FMUSP) - São Paulo (SP), Brasil.

2 Professor Livre Docente em Neonatologia pela FMUSP, Médico Assistente do CTIN2 do Instituto da Criança do HCFMUSP - São Paulo (SP), Brasil.

3 Doutora em Ciências pela FMUSP e Médica Assistente do CTIN2 do Instituto da Criança do HCFMUSP - São Paulo (SP), Brasil. Corresponding author:

Suggested citation: Ceccon MEJ, Redondo AC, Feferbaum R, Vieira RA, Moreira DAR, Tannuri U, Carvalho WB. Characteristics of the clinical development of a newborn with gastroschisis in an intensive care unit in latin america. J Hum Growth Dev. 26(2): 190-198. Doi: http://dx.doi.org/10.7322/jhgd.119266

Manuscript submitted: Mar 12 2016, accepted for publication Apr 162016 
temporal increase of 2.23 per 10,000 live births to 4.42 per 10,000 Regarding the definition of live births. The current prevalence in South America is 2.9:10,0005.

This disease is characterised by a defect in abdominal wall closure with herniation of the intestines and other abdominal organs into the amniotic cavity. The herniation is usually in the right periumbilical region, but may occur in some patients on the left underside ${ }^{6}$.

The literature relates the increase in this disease with pregnancy at the age of 20 years, smoking, illicit drug use, and placental insufficiency with poor foetal oxygenation. Some authors report as a possible aetiology the use of substances as pseudoephedrine in nasal decongestants and environmental toxins. The possibility of a genetic aetiology is always present, as children from the same mother can have this problem. The most frequently observed risk factor is teenage pregnancy $^{7-10}$.

A prenatal diagnosis can be performed by measuring the alpha-fetoprotein produced by the foetal gastrointestinal tract and liver as well as foetal ultrasonography, which is considered the gold standard for diagnosis. The problem is diagnosed in the first routine ultrasound performed on the mother. This imaging test can show problems with the lateral abdominal wall and insertion of the cord, which is inserted normally. The viscera are observed floating in the amniotic fluid without membrane structures, generally including the small intestine, large intestine, stomach, appendix, fallopian tubes and ovaries, as well as portions of the urinary and/ or reproductive tract. Prenatal care is of great importance since early termination of pregnancy may occur due to changing foetal vitality. Although it does not seem to increase morbidity or mortality in vaginal delivery, often these deliveries are performed by caesarean section ${ }^{11,12}$.

Mortality rates range from 3 to $10 \%$, and high morbidity in the neonatal period is associated with factors related to slow post-operative intestinal adaptation with the use of prolonged parenteral nutrition (PPN), causing cholestasis associated with parenteral nutrition (CAPN) and central venous catheters (CVC) use for a prolonged period, infections and the presence of hydroelectrolytic disturbances associated with renal insufficiancy ${ }^{12}$. The complexity of this malformation depends on its association with intestinal atresia, perforation, necrosis and volvulus, which makes the surgical management needed evolve to a short bowel syndrome frame, prolongs the hospital stay and promotes a number of comorbidities ${ }^{13}$.

The objective of this study was characterise the clinical outcome of newborns with gastroschisis in a neonatal intensive care unit.

\section{METHODS}

This was a retrospective observational clinical study, conducted from October 2011 to October 2014, which included 50 newborns (NB) diagnosed with gastroschisis and transferred for treatment to Neonatal Intensive Centre 2 (CTIN2) of the Children's Institute at Hospital das Clinicas, Faculty of Medicine, University of
São Paulo (HCFMUSP). The only exclusion criteria were infants who had other abdominal wall defects.

The following data were collected from patient records: maternal parameters (age, parity, prenatal diagnosis during prenatal care, gestational age, mode of delivery, use of licit or illicit drugs), newborn parameters (birth weight, Apgar score, gender, intestinal malformations and extraintestinal problems, hospital stay and mortality) and surgical treatment (time from birth to the initial surgical approach, the technique used and the number of reoperations).

The criteria for GS classification was done according to its complexity based on the presence of associated bowel abnormalities, inability to perform primary total surgical reduction and the necessity for reoperation. Thus, the patients were classified into noncomplex and complex GS. Enteral nutrition was considered when it occurred by an orogastric or oral probe during at least 24 hours. Regarding the definition of infection, this group included all patients with a clinical status, as defined by the Surviving Sepsis Campaign 14 after the first 72 hours of life, who presented or not a positive culture in sterile secretions. Infection associated with catheter use was considered when infectious agent was identified in central and peripheral culture. Hyponatraemia was defined as serum sodium $<135 \mathrm{mEq} / \mathrm{L}$ and hypoalbuminaemia as serum albumin $<3 \mathrm{~g} / \mathrm{dL}$. No patient received diuretics during the assessment period.

The NB data were recorded using a specific data collection form and compiled in a spreadsheet using the GraphPad statistical package Prism version 6.0c (GraphPad Software, La Jolla, California, United States). The qualitative variables were analysed by calculating the absolute and relative frequencies, while the described quantitative variables were analysed by calculating the median and the minimum and maximum values. The Mann-Whitney test was used to compare the median data between groups, while for the comparative analysis of the medians of more than two groups used the Kruskal-Wallis test with Dunn's post-test. The tests were performed with a confidence interval limits of $95 \%$ and a p-value $<0.05$ was considered significant.

\section{RESULTS}

During the three years of the research, 50 NB were admitted to the CTIN2 diagnosed with gastroschisis (GS) (Table 1). There was no difference in relation to female (26 cases) and male (24 cases) gender. Gestational age and the average weight at birth was $361 / 7$ weeks and 2309 g, respectively. In the group of mothers, six (12\%) had a diagnosis of foetal malformation just after delivery, although all had received prenatal care. The total of 43 pregnant women (86\%) underwent caesarean delivery and $77 \%$ were pregnant for the first time with an average age of 20.8 years.

The median age of the NB upon hospital admission for surgical correction was 2 hours, with a maximum of 6 days. According to the charts, none of the patients 
Table 1: Demographic characteristics of the 50 patients diagnosed with gastroschisis

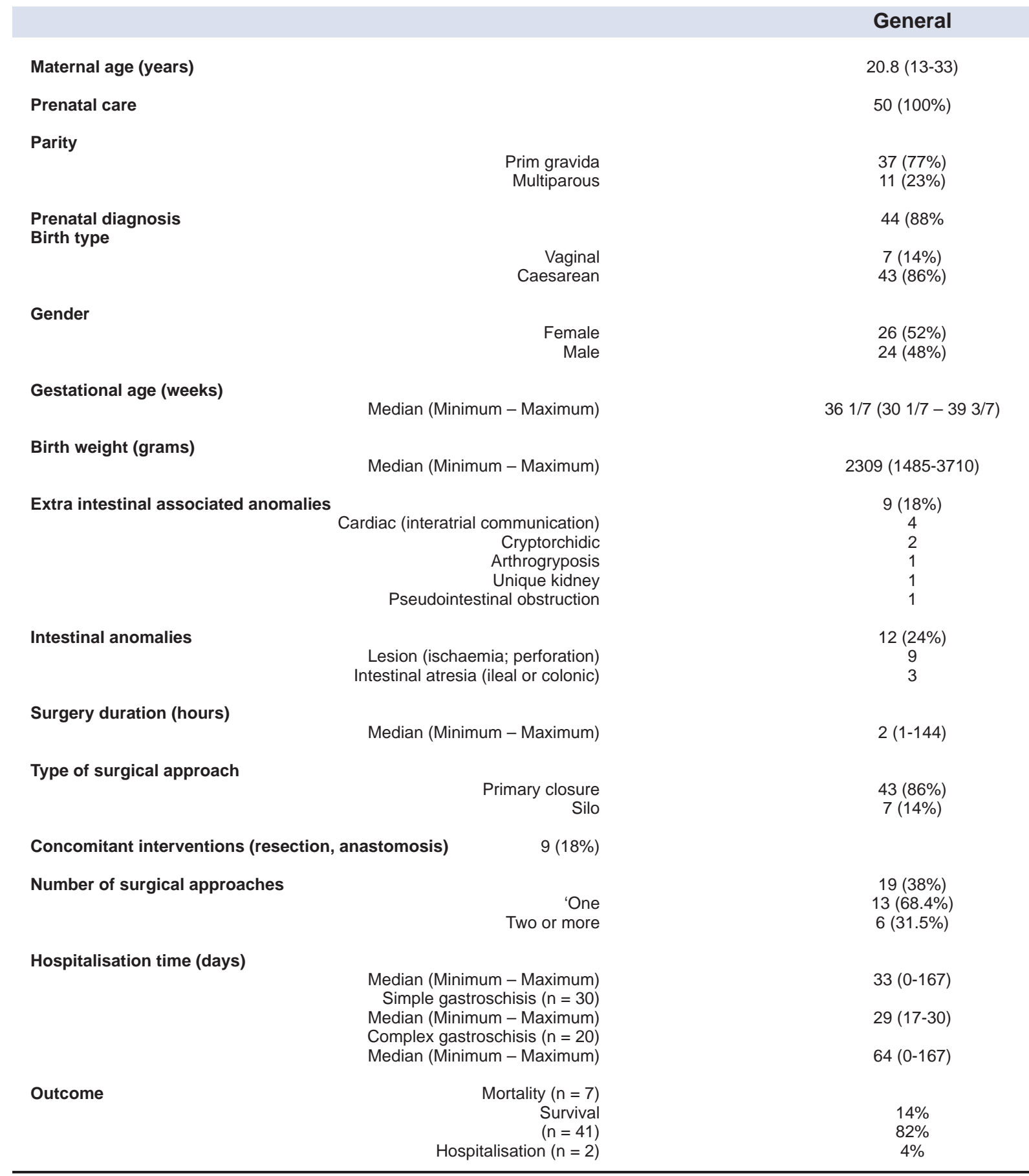

presented with perinatal asphyxia based on the Apgar score. Of the 50 patients, $86 \%$ were submitted to primary correction of the defect in the abdominal wall, while $14 \%$ opted for initial use of a silo due to ventilatory and haemodynamic instability observed during the primary reduction of intestinal loops. The silo is a silicone bag, which protects the intestinal loops that after the surgery were still externalised from the abdomen, due to the impossibility of placing the intestinal contents inside immediately, or because the child presented hemodynamic instability. There was an association with other malformations in $24 \%$ of NB and there was the need for an additional surgical approach in 19 patients due to bowel obstruction, perforation, volvulus or closure of the abdominal wall with removal of the previously used silo.

General mortality observed was $14.5 \%$ (seven patients). The median length of stay of patients receiving hospital discharge was 33 days (maximum of 140 days and a minimum of 17 days), and was longer (median 56 days, maximum 140 days and minimum 24 days) in those with complex GS (multiple surgical approaches or with an associated intestinal anomaly). Table 2 shows the characteristics of the NB who died during hospitalisation. 
Table 2: Demographic characteristics of seven patients diagnosed with gastroschisis who died during hospitalization

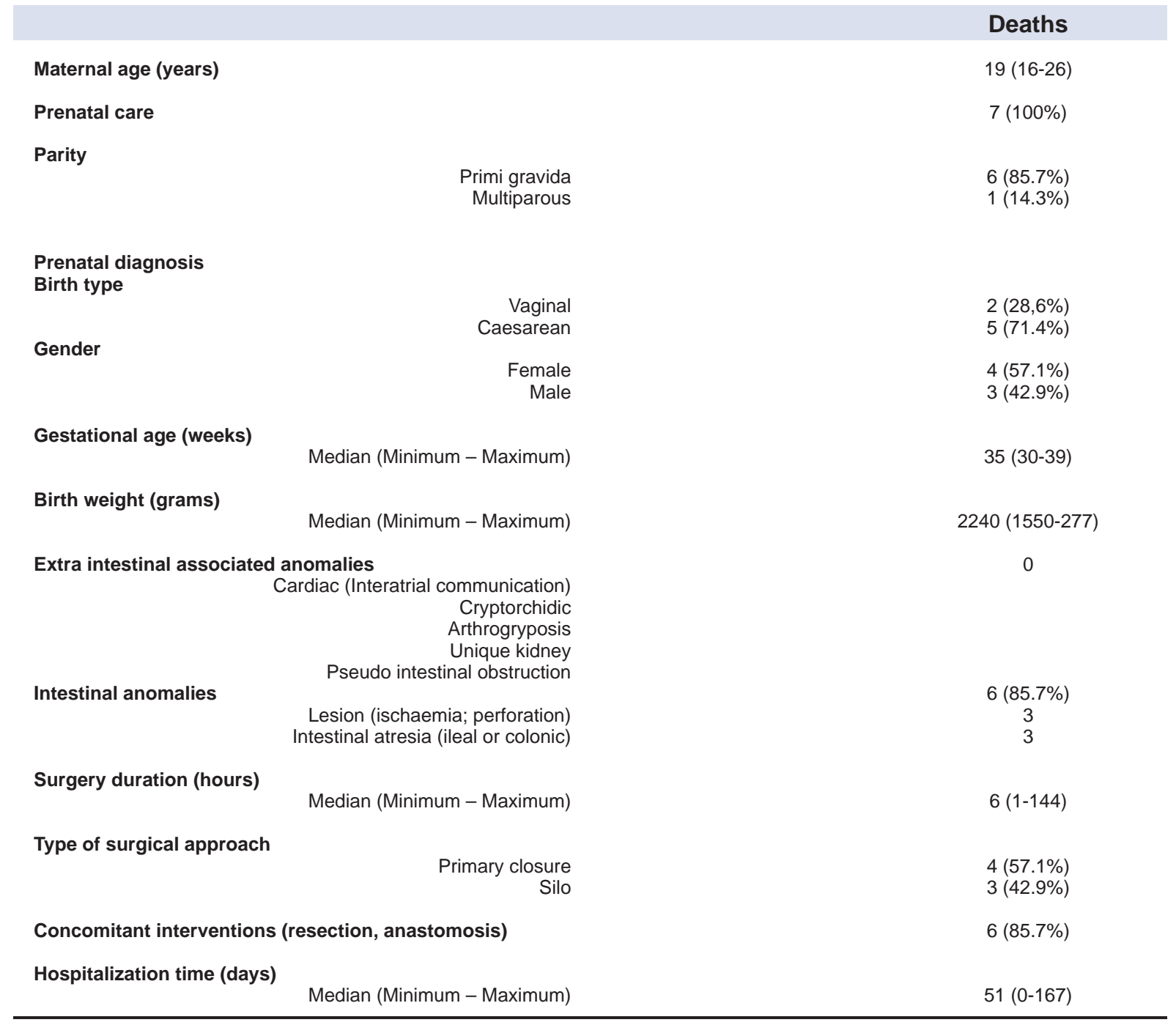

The deceased patients showed a higher prevalence of intestinal anomalies and a consequent need for concomitant interventions in the first surgical approach, in addition to longer hospitalisation.

\section{Renal adaptation}

The general evolution of the urine output in patients submitted to surgical correction is shown in Table 3. Although all patients achieved effective urine output within

Table 3. Newborn diuresis evolution in the GS postoperative period

\begin{tabular}{lcc} 
Time & $\begin{array}{c}\text { Diuresis }(\mathbf{m L} / \mathbf{k g} / \mathbf{h}) \\
\text { Median }(\text { Minimum }- \text { Maximum) }\end{array}$ & Oligoanuria \\
\hline 6 hours & $0.3(0-4.7)$ & $\mathrm{n}=19$ \\
12 hours & $1.6(0-4)$ & $\mathrm{n}=11$ \\
24 hours & $1.9(0-6.9)$ & $\mathrm{n}=5$ \\
36 hours & $2.7(0.5-8.5)$ & $\mathrm{n}=5$ \\
48 hours & $3.5(1.1-11.5)$ & $\mathrm{n}=0$ \\
\hline
\end{tabular}

48 hours post-op, five patients (12.5\%) remained oliguric following 36 hours of evolution.

Of all patients, 35 (70\%) presented hyponatraemia with serum sodium levels varying between 110 and 133 $\mathrm{mEq} / \mathrm{L} ; 20$ (57\%) presented with oliguria (urinary debit $<-1.00 .5 \mathrm{~mL} / \mathrm{kg} /$ hour) or oligoanuria. Only three NB did not evolve with changing serum sodium and urine output (diuresis). Natraemia normalisation occurred after the fifth day of evolution in all patients. There were no differences regarding natraemia and fasting time ( $p=0.79$ ). The newborns at term received during the first and second day $80 \mathrm{~mL} / \mathrm{kg} /$ weight water volume, i.e. $20 \mathrm{~mL}$ 
more than normally prescribed on these days for newborns at term, while the pre-terms received $90 \mathrm{~mL} / \mathrm{kg}$ due to the big insensitive loss that occurs in these NB, due to externalisation of the handles in the abdominal cavity. In the first 48 hours of life, infants did not receive electrolytes, and after surgery, the fluids and electrolytes provided depended on the water-electrolyte balance of each patient.

Regarding the dosage of serum albumin, this was provided at a median of $2.4 \mathrm{~g} / \mathrm{dL}$ (minimum $1 \mathrm{~g} / \mathrm{dL}$ and maximum $3.6 \mathrm{~g} / \mathrm{dL}$ ).

\section{Nutrition}

All patients started PPN on the first day of life. The PPN composition was customised according to the needs of the patient considering gestational age and post-surgical stress. The lipid portion was composed of a lipid emulsion up to $20 \%$ with medium chain triglycerides (MCT) or $20 \%$ lipid emulsion of MTC and oils of soy, olive and fish (MTC/olive/soy/fish 20\%), following established practice in the service during the period of hospitalisation of the patient. This customised solution provided the maximum supply of amino acids, and on the third day of life, the individual tolerance was evaluated based on laboratory tests of kidney function and the intensity of cholestasis according to the dosage of copathological correlation and liver enzymes of the NB (Table 4).

The analysis of patients with regard to nutritional development and the type of GS (simple or complex) showed that there was no difference between the registered weight at birth and the beginning of an enteral diet. Although the weight was 1.5 times higher in patients with complex GS in the case outcome, weight gain per day of hospitalisation was significantly higher in patients with simple GS ( $p=0.023$ ). This weight gain was similar during the usage of PNN in two groups, and was significantly higher in patients with simple GS after the introduction of an enteral diet $(\mathrm{p}=0.0046)$. Greater height gain was found at hospital discharge in patients with simple compared to GS with complex GS ( $p=0.014)$ (Table 4).

In relation to the diagnosis of cholestasis, this was observed 2.4 times more frequently in patients with complex GS when compared to patients with simple GS. Regardless of the presence of cholestasis, there was an increase in the dosage of serum GS in patients with complex GS (p = 0.0013) (Table 4).

Table 4: Nutritional condition of 50 patients with GS (Mann-Whitney test)

\begin{tabular}{|c|c|c|c|}
\hline & $\begin{array}{c}\text { Simple GS }(\mathbf{n}=\mathbf{2 9}) \\
\text { Median } \\
\text { (Minimum - Maximum) }\end{array}$ & $\begin{array}{c}\text { Complex GS }(\mathbf{n = 2 1 )} \\
\text { Median } \\
\text { (Minimum - Maximum) }\end{array}$ & $\mathbf{P}$ \\
\hline Fasting total time (days) & $19(10-49)$ & $38(14-81)$ & $0.0002^{*}$ \\
\hline \multicolumn{4}{|l|}{ Weight (grams) } \\
\hline Birth & 2380 (1570-3710) & 2240 (1485-2990) & 0.56 \\
\hline Beginning of enteral diet & 2678 (1980-4175) & 3090 (1980-4480) & 0.077 \\
\hline Outcome & 3010 (2140-4250) & $2240(1485-2990)$ & 0.56 \\
\hline $\begin{array}{l}\text { Time to reach full die } \\
\text { (days) }\end{array}$ & $5.5(3-25)$ & $6(3-118)$ & 0.37 \\
\hline PPN 20\% & $4(13.8 \%)$ & $2(9.5 \%)$ & - \\
\hline IL 20\% com MCT & $9(31 \%)$ & $4(19 \%)$ & \\
\hline MCT/soya/olive/fish & $16(55.2 \%)$ & $14(66.7 \%)$ & \\
\hline $20 \%$ & 0 & $1(4.8 \%)$ & \\
\hline \multicolumn{4}{|l|}{ PPN absence } \\
\hline PPN time (days) & $23(13-67)$ & $45(20-171)$ & $0.0002^{*}$ \\
\hline \multicolumn{4}{|l|}{ Ponderable gain (g/day) } \\
\hline Exclusive PPN & $18(1-42)$ & $17(6-26)$ & 0,76 \\
\hline Enteral diet & $28(8-58)$ & $17(4-42) 5$ & $0.0046^{*}$ \\
\hline During hospitalisation & $22(8-38)$ & $16(8-27)$ & 0.023 \\
\hline Length (cm/week) & $3.9(0.6-7.8)$ & $2.8(1.3-4.8)$ & $0.014^{*}$ \\
\hline Cholestasis & $9(31 \%)$ & $16(76 \%)$ & $0.0004^{*}$ \\
\hline GGT (U/L) & $161.5(104-651)$ & $622(53-1875)$ & $0.0013^{*}$ \\
\hline AP (U/L) & 454 (178-640) & 538 (220-957) & 0.18 \\
\hline
\end{tabular}

* $\mathrm{p}<0.05$; GS = gastroschisis; PPN = prolonged parenteral nutrition; IL = intralipids; MCT = medium chain triglycerides; GGT = gamma glutamyl transferase; AP = alkaline phosphatase.

\section{Infection}

There was a 58\% frequency of late sepsis (29 cases) among the $50 \mathrm{NB}$ with simple and complex GS; $37.9 \%$ (11 cases) of infections were associated with the use of CVC. Patients who presented late sepsis did not differ regarding the gestational age, sex, weight or time elapsed before the initial surgical approach when compared to patients who showed no infection (Table 5).

The time of hospitalisation and invasive mechanical ventilation was higher in those patients who had complex GS and who required more than one surgical approach $(\mathrm{p}<0.0001)$. As expected, the use of blood products in those patients was higher, except for the use of fresh plasma, which was similar in the three groups $(p=0.12)$ (Table 5$)$.

Of the patients without infection, three underwent an additional surgery 4, 6 and 18 days later to remove the silo in the first two cases and due to a late resection for jejunal atresia in the third patient. The length of stay was 44, 43 and 44 days, respectively (Table 5). 
Table 5: Late-onset sepsis in 50 newborns with GS (multivariate analysis - ANOVA)

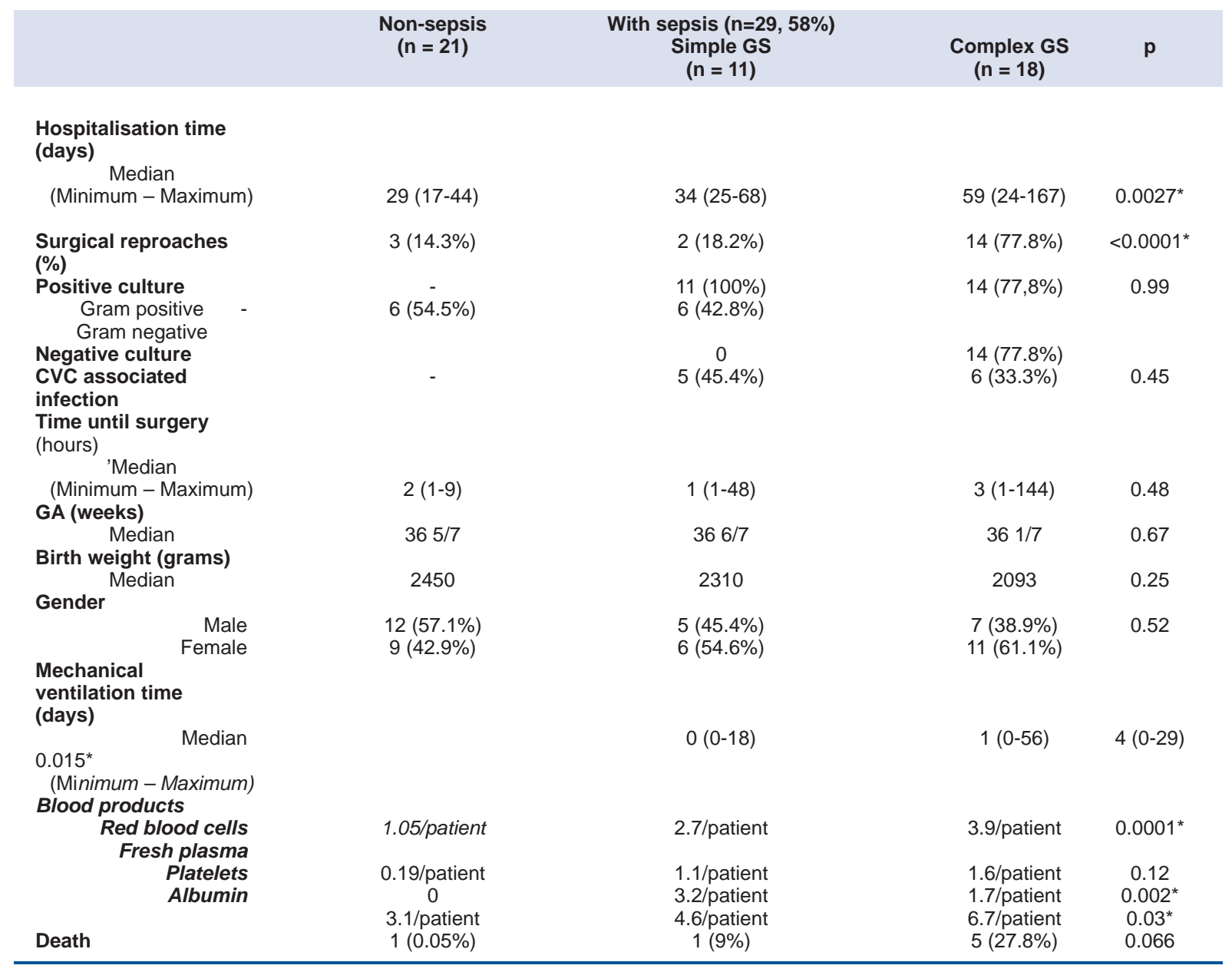

GS = gastroschisis; CVC= central venous catheter; GA = gestational age; ${ }^{\star} p<0.05$;

\section{DISCUSSION}

The experience of the Neonatology Service of reference in Latin America in the clinical management of patients with gastroschisis emphasises three challenging medical conditions to the neonatal intensive care specialist physician: renal adaptation, nutrition and infection.

Several clinical papers ${ }^{5-8}$ show that the prevalence of GS has increased significantly in recent years throughout the world, i.e. by $67 \%$ in two years. This fact, coupled with a usually prolonged hospitalisation, has led to a high burden on the public health service regarding the care of these patients.

The general mortality of $14 \%$ observed in this study is higher than that described in the literature, probably because of the complexity of the patients due to the high prevalence of intestinal anomalies and multiple surgical interventions (24\% and $38 \%$ of cases, respectively). In relation to maternal age, we observed the same trend described in the literature, i.e. an association between malformation and young mothers. Among all mothers, only $36 \%$ were older than 21 years of age.

One factor to be considered concerns the delivery route chosen for patients with this type of malformation. We observed that, unlike the practice adopted in other countries, where vaginal birth is chosen regardless of malformation, surgical birth was preponderant in our series (86\% of cases) as it offered better initial surgical treatment and optimised management.

Term newborns delivered vaginally were transferred from another hospital in $71 \%$ of cases. Only one NB (14\%) showed no drilling, ischemia or necrosis of handles that culminated with extensive bowel resection and short bowel syndrome, which shows a lack of preparation in the initial care in the delivery room and neonatal transport.

In relation to hydroelectrolytic and renal adaptation, some studies have shown that the monitoring of intraoperative intra-abdominal pressure confers benefits to patients because it added a given goal facing the decision of primary surgical correction or interposition of silo, until better accommodation of the intestinal loops could be achieved ${ }^{15,16}$. In the cases presented in this study, intraoperative hemodynamic instability and post-surgical urinary flow recovery were used to inform this decision.

The evaluation of renal function by urine output during the first 48 hours of life is inaccurate, since oliguria ( $<0.5-1.0 \mathrm{~mL} / \mathrm{kg} /$ hour $)$ may be caused by oligoanuria 
in the postnatal period and secondary hypovolemia/ prerenal insufficiency to big insensitive loss caused by exteriorisation of the intestinal loops and a decrease in renal perfusion pressure caused by the sudden and inevitable rise in intra-abdominal pressure in the immediate postoperative period ${ }^{17,18}$.

Although all patients in the study recovered urine output within 48 hours after surgery, the concern in this period is to the need to recover renal function, with the preferable treatment by volume expansion with colloid solution (20\% human albumin diluted in half with 5\% dextrose) in $98 \%$ of patients. Despite the water restriction adopted, the development of hyponatraemia was observed in $70 \%$ of cases, which is associated with increased morbidity and mortality in the literature.

Nutrition is one of the biggest challenges in the management of patients with GS. The time to restore intestinal transit varies, especially in association with intestinal atresia, ischemic injury or extensive surgical resection. The fasting time for patients with simple GS in our series (median 19 days) was similar to that found in the literature, with weight gain during PPN similar to that expected in eutrophic patients on enteral nutrition (22 g/ $\mathrm{kg} /$ day).

PPN in these children is a challenge, not only due to the difficulties associated with hydroelectrolytic and glucose control, but also due to the association between prolonged fasting and frequent episodes of bacterial sepsis, causing almost always a cholestasis associated to parenteral nutrition (CANP) framework, characterised by increased direct bilirubin and liver enzymes. The severity and progression of this case often affects the maintenance of PPN or even makes it unfeasible since the proposed treatment is a reduction of amino acids and lipid emulsion, resulting in an unsatisfactory supply of nutrients for proper growth $^{19,20}$.

The recent introduction of a $20 \%$ lipid emulsion with fish oil (omega-3) brought a better outlook in the control of CANP ${ }^{19}$. The replacement of the $20 \%$ lipid emulsion (20\% Lipid® SMOF), consisting of fish and olive oils as well as long chain triglycerides (TCM/TCL) increased direct bilirubin and liver enzymes. A decrease in these indicators allows for the maintenance of adequate protein-calorie offering PPN and satisfactory weight gain $^{19-21}$.

It was found in experimental studies of rabbit foetuses with induced GS that a reduction occurred in the absorption of amino acids and glucose compared to the control group, along with a decrease in the expression of genes involved in the absorption of nutrients in enterocytes ${ }^{21,22}$. In the patients in our study, refeeding was hampered by intestinal dysmotility with frequent episodes of vomiting and abdominal distension. Slow introduction in small volumes of formulae based on protein hydrolysates was used in most cases. However, the requirement of human milk, when possible, has better indication.

Sepsis is a major cause of morbidity and mortality in NBs, despite advances in intensive care ${ }^{23,24}$. It is believed that the severity of the clinical evolution of sepsis is due to several factors, such as prematurity and varying degrees of deficiencies in the innate and adaptive immune responses ${ }^{25-27}$, which affect the interaction between the host and the infectious agent with, consequently, an impact on the cascade of events comprising the immune response.

Despite this greater susceptibility of NB to infectious conditions, it has been observed that, in patients with GS, other predisposing factors also contribute, such as exposure of the viscera to the external environment, prolonged fasting with a greater possibility of bacterial translocation, the need for long-term venous access for PPN and surgical approaches with the possibility of intestinal handling.

A study by Baird et al. ${ }^{28}$ showed surgical wound infection in $12.6 \%$ of cases and infection associated with CVC in $14.9 \%$, particularly with coagulasenegative staphylococci. Still, the authors demonstrated the importance of early closure of the abdominal wall and infectious complications. A high frequency of late sepsis (58\%) was observed in the present study; $37.9 \%$ of infections were associated with the use of CVC. Despite the wide availability of using peripherally inserted central catheters in routine service (86\% of patients) and their association with lower rates of infection in the literature, the high rate of infection associated with venous catheters observed in our study raises an alert regarding the care and guidance of antimicrobial therapy, as $72.7 \%$ of these infections were related to Staphylococcus epidermidis.

Success in the treatment of gastroschisis depends on the joint efforts of a highly trained multidisciplinary health care team and the development and implementation of a proper care protocol at each institution, taking into account the clinical surgical complications of this complex neonatal pathology.

\section{REFERENCES}

1. Sekhobo JP, Druschel CM. An evaluation of congenital malformations surveillance in New York State: An application for Centers for Disease Control and Prevention (CDC) guidelines for evaluating surveillance systems. Public Health Rep. 2001;116(4):296-305.

2. Amorim MMR, Vilela PC, Santos ARVD, Lima ALMV, Melo EFP, Bernardes HF et al. Impacto das malformações congênitas na mortalidade perinatal e neonatal em uma maternidade-escola do Recife. Rev Bras Saúde Matern Infant. 2006;6(Supl 1):S19-S25. DOI: http://dx.doi.org/10.1590/S1519-38292006000 500003

3. Castilha EE, Mastroiacovo P, Orioli IM. Gastroschisi: international epidemiology and public health perspectives. Am J Med Genet. 2008;148C(3):162-79. DOI: http://dx.doi.org/10.1002/ajmg.c.30181 
4. Kirby RS, Marshall J, Tanner JP, Salemi JL, Feldkamp ML, Marengo L, et al. Prevalence and correlates of gastroschisis in 15 states, 1995 a 2005. Obstet Gynecol. 2013;122(2 Pt 1):275-81. DOI: http://dx.doi. org/10.1097/AOG.0b013e31829cbbb4

5. Ledbetter DJ. Gastroschisis and omphalocele. Surg Clin N Am. 2006;86(2):249-60. DOI: http://dx.doi. org/10.1016/j.suc.2005.12.003

6. Feldkamp ML, Botto LD. Developing a research and public health agenda for gastroschisis: How do we brige the gap between what is know and what is not? Am J Med Genet C Semin Med Genet. 2008;148C(3):15561. DOI: http://dx.doi.org/10.1002/ajmg.c.30183

7. Curry JL, McKinney P, Thornton JG, Stringer MD. The aetiology of gastrosquisis. BJOG. 2000; 107(11): 1339-46. DOI: http://dx.doi.org/10.1111/j.1471-0528.2000.tb11645.x

8. Nichol PF, Byrne JLB, Dodgion C, Saijoh Y. Clinical consideration in gastroschisis. Incremental advances against a congential anomaly with severe secondary effectas. Am J Med Genet C Semin Med Genet. 2008;148C(3):231-40. DOI: http://dx.doi.org/10.1002/ajmg.c.30180

9. Rasmussen SA, Frias JL. Non genetic risk factors for gastroschisis. Am J Med Genet C Semin Med Genet 2008;148C(3):199-212. DOI: http://dx.doi.org/10.1002/ajmg.c.30175

10. Byrne JLB, Feldkamp ML. Seven-week embryo with gastroschisis, multiple anomalies and physiologic hernia suggest early onset of gastroschisis. Birth Defects Res A Clin Mol Teratol. 2008;82(4):236-8. DOI: http://dx.doi.org/10.1002/bdra.20446

11. Paidas MJ, Crombleholme TM, Robertson FM. Prenatal diagnosis and management of the fetus with an abdominal wall defect. Semin Perinatol 1994;18(3):196-214.

12. Burge DM, Ade-Ajayi N. Adverse outcome after prenatal diagnosis of gastroschisis: the role of fetal monitoring. J Pediatr Surg. 1997;32(3):441-4. DOI: http://dx.doi.org/10.1016/S0022-3468(97)90601-1

13. Sydorak RM, Nijagal A, Sbragia L, Hirose S, Tsao K, Phibbs RH, et al. Gastroschisis: small hole, big cost. J Pediatr Surg. 2002;37(12):1669-72. DOI: http://dx.doi.org/10.1053/jpsu.2002.36689

14. Alshehri A, Emil S, Laberge JM, Skarsgard E; The Canadian Pediatric Surgery Network. Outcomes of early versus late intestinal operations in patients with gastroschisis and intestinal atresia: results from a prospective national database. J Pediatr Surg. 2013;48(10):2022-6. DOI: http://dx.doi.org/10.1016/j. jpedsurg.2013.04.003

15. Dellinger RP, Levy MM, Rhodes A, Annane D, Gerlach H, Opal SM, et al. Surviving sepsis campaign: international guidelines for management of severe sepsis and septic shock: 2012. Int Care Med. 2013;41(2):580-637. DOI: http://dx.doi.org/10.1097/CCM.0b013e31827e83af

16. Schmidt AFS, Gonçalves A, Bustorff-Silva JM, Oliveira-Filho AG, Miranda ML, Oliveira ER, et al. Monitoring intravesical pressure during gastroschisis closure. Does it help to decide between delayed primary or staged closure? J Matern Fetal Neonatal Med. 2012;25(8):1438-41. DOI: http://dx.doi.org/10.3109/14767 058.2011 .640366

17. Schmidt AF, Gonçalves A, Bustorff-Silva JM, Oliveira Filho AG, Marba ST, Sbragia L. Does staged closure have a worse prognosis in gastroschisis? Clinics. 2011;66(4):563-6. DOI: http://dx.doi.org/10.1590/S180759322011000400007

18. Santos MM, Tannuri U, Maksoud JG. Alterations of enteric nerve plexus in experimental gastroschisis: is there a delay in the maturation? J Pediatr Surg. 2003;38(10):1506-11. DOI: http://dx.doi.org/10.1016/ S0022-3468(03)00504-9

19. Tannuri ACA, Sbragia L, Tannuri U, Silva LM, Leal AJG, Schmidt AFS, et al. Evolution of critically ill patients with gastroschisis from three tertiary centers. Clinics. 2011;66(1):17-20. DOI: http://dx.doi.org/10.1590/ S1807-5932201100010000

20. Tannuri ACA, Silva LM, Leal AJG, Ricardi LRS, Tannuri . Qual é a melhor solução de hidratação parenteral a ser utilizada no tratamento pós-operatório de recém-nascidos com gastrosquise? Experiência do Instituto da Criança do Hospital das Clínicas da Faculdade de Medicina da USP. Pediatr. 2010;32(2):84-9.

21. Feferbaum R, Leone C, Cruciani J, Alves P, Tomaz B, Maluvayshi C, et al. PP252-MON: lipid emulsion with fish oil improves associated parenteral nutrition cholestasis in neonates with gastrointestinal exclusion. Clin Nutrition. 2014;33(Suppl 1):S223. DOI: http://dx.doi.org/10.1016/S0261-5614(14)50586-9

22. Shaw K, Buchmiller TL, Curr M, Lam MM, Habib R, Chopourian HL, et al. Impairment of nutrient uptake in a rabbit model of gastroschisis. J Pediatr Surg. 1994;29(3):376-8. DOI: http://dx.doi.org/10.1016/00223468(94)90570-3

23. Srinathan SK, Langer JC, Wang JL, Rubin DC. Enterocytic gene expression is altered in experimental gastroschisis. J Surg Res. 1997;68(1):1-6. DOI: http://dx.doi.org/10.1006/jsre.1996.4986

24. Camacho-Gonzalez A, Spearman PW, Stoll BJ. Neonatal infectious diseases: evaluation of neonatal sepsis. Pediatr Clin North Am. 2013;60(2):367-89. DOI: http://dx.doi.org/10.1016/j.pcl.2012.12.003

25. Viemann D, Dubbel G, Schleifenbaum S, Harms E, Sorg C, Roth J. Expression of toll-like receptors in neonatal sepsis. Pediatr Res. 2005;58(4):654-9. DOI: http://dx.doi.org/10.1203/01.PDR.0000180544.02537.FD 
26. Kollmann TR, Crabtree J, Rein-Weston A, Blimkie D, Thommai F, Wang XY, et al. Neonatal innate TLRmediated responses are distinct from those of adults. J Immunol. 2009;183(11):7150-60. DOI: http:// dx.doi.org/10.4049/jimmunol.0901481

27. Russell ARB. Neonatal sepsis. Paediatr Child Health. 2011;21(6):265-9. DOI: http://dx.doi.org/10.1016/j. paed.2010.11.003

28. Baird R, Puligandla P, Skarsgard E, Laberge JM; Canadian Pediatric surgical Network. Infectious complications in the management of gastroschisis. Pediatr Surg Int. 2012;28(4):399-404. DOI: http:// dx.doi.org/10.1007/s00383-011-3038-6

This article is distributed under the terms of the Creative Commons Attribution 4.0 International License (http://creativecommons.org/licenses/by/4.0/), which permits unrestricted use, distribution, and reproduction in any medium, provided you give appropriate credit to the original author(s) and the source, provide a link to the Creative Commons license, and indicate if changes were made. The Creative Commons Public Domain Dedication waiver (http://creativecommons.org/publicdomain/zero/1.0/) applies to the data made available in this article, unless otherwise stated.

\section{Resumo}

Introdução: As malformações congênitas fazem parte das principais doenças observadas ao nascimento. Entre as causas de óbito no período neonatal as malformações foram a segunda causa, sendo ainda a primeira, a prematuridade.

Objetivos: Caracterizar a evolução clínica dos recém-nascidos (RN) com gastrosquise (GTQ) em uma unidade de terapia intensiva neonatal e descrever as morbidades renal, nutricional e infecciosa relacionados ao manejo clínico pós-natal na unidade de terapia intensiva neonatal.

Método: Foi realizado estudo observacional retrospectivo em 50 RN com GTQ, utilizando a associação de anormalidades intestinais, impossibilidade de fechamento primário do defeito abdominal e necesidade de reoperação como critérios de classificação para a doença. O nível de significância foi p $<0,05$.

Resultados: A admissão hospitalar para cirurgia primária ocorreu com mediana de idade de 2 horas. 0 total de $14 \%$ das crianças foram submetidas a uma interposição de silo primária e $24 \%$ apresentaram malformação intestinal associada. Dezenove RN necessitaram mais de uma intervenção cirúrgica. A mediana do tempo de estadia foi de 33 dias, sendo maior nos pacientes com GTQ complexa (56 dias). Todos os RN recuperaram o débito urinário a partir de 48 horas do pós-operatório e $40 \%$ apresentaram hiponatremia e oligoanúria nesse período. Não houve diferença entre a natremia e o tempo de jejum $(p=0,79)$. O ganho ponderal foi similar em ambos os grupos com nutrição parenteral total e tornou-se significativamente maior nos pacientes com GTQ simples após a alimentação enteral $(p=0,0046)$. Esses RN evoluíram 2,4 vezes com menos colestase. Sepse tardia ocorreu em 58\% dos pacientes e foi relacionada à infecção do CVC em 37,9\% dos casos. A mortalidade foi maior nos RN infectados com GTQ complexa e a taxa global de mortalidade foi de $14 \%$.

Conclusão: A caracterização clínica dos RN com GTG depende da complexidade e do conhecimento e condução das morbidades para diminuir a mortalidade.

Palavras-chave: gastrosquise, recém-nascido, mortalidade, nutrição parenteral total, insuficiência renal, infecção. 